\title{
Türk Kamu Yönetiminde Personel Motivasyonu ve Verimlilik Üzerine Etkileri Erzurum Bölge Adliye Mahkemesi Örneği ${ }^{1}$
}

\section{Example of Erzurum Regional Court of Justice in Turkish Public Administration on Staff Motivation and Efficiency}

\section{Dr. Öğr. Üyesi Abdulsemet YAMAN ${ }^{1}$ - Murat DUYSAK ${ }^{2}$}

Başvuru Tarihi: 17.12.2019

Kabul Tarihi: 06.03.2020

Makale Türü: Araştırma Makalesi

Öz

Motivasyon insanı harekete geçiren, davranışlarını yönlendiren olgulardır. Verimlilik ise eldeki kaynaklarla en çok çıktıya ulaşma çabasıdır. İnsanlar fiziksel, duygusal ve düşünsel farklılıklara sahiptir. Bu durum insanların motivasyonunu etkileyen faktörlerin farklılaşmasına neden olmuştur. Bu farklılıklardan hareketle insanı harekete geçiren motivasyon faktörlerinin belirlenmesi ve ölçümü ile motivasyon faktörlerinin verimlilik üzerine etkilerine yönelik yargı özelinde literatür eksikliği bulunmaktadır.

Bu çalışmanın temel amacı, yargı süreçlerinin hızlandırılması noktasında kamu personellerinin motivasyonu ve verimlilik üzerine etkilerinin araştırılmasıdır. Bu amaçla çalışma, Türk yargı sisteminde faaliyet gösteren Erzurum Bölge Adliye Mahkemesi’nde çeşitli unvanlarda görev yapan çalışanlar ile gerçekleştirilmiştir. Çalışma kapsamında anket tekniği kullanılarak çalışanların konuya ilişkin algıları ölçülmeye çalışılmıştır. Bu çerçevede teorik bilgilere yer verilerek anket sonucu elde edilen bulgular ortaya konulmuştur.

Anahtar Kelimeler: Bölge Adliye Mahkemesi, Personel Motivasyonu, Türk Kamu Yönetimi, Verimlilik

\footnotetext{
1 Bu çalışma, Murat DUYSAK” ın, “Türk Kamu Yönetiminde Personel Motivasyonu ve Verimlilik Üzerine Etkileri Erzurum Bölge Adliye Mahkemesi Örneği” konulu Yüksek Lisans tezinden türetilmiştir.

1 Ardahan Üniversitesi, İktisadi Ve İdari Bilimler Fakültesi, abdulsemetyaman@ardahan.edu.tr, ORCID: 0000000242908063

2 Ardahan Üniversitesi Siyaset Bilimi ve Kamu Yönetimi, Yüksek Lisans programı mezunu, murat.duysak25@gmail.com, ORCID: 0000 0002 22021086
} 


\begin{abstract}
Motivation is the facts that motivate the human and directs their behavior. Productivity is the effort to reach the most output with the resources available. People have physical, emotional and intellectual differences. This situation caused different factors affecting the motivation of people. Based on these differences, there is a lack of literature about the determination and measurement of motivation factors that motivate people and the effects of motivation factors on productivity.
\end{abstract}

The main aim of this study is to investigate the effects of public personnel on motivation and efficiency in accelerating judicial processes. For this purpose, the study was carried out with the employees working in various titles in the Erzurum Regional Court of Justice, which operates in the Turkish judicial system. Within the scope of the study, the employees' perceptions about the subject were tried to be measured by using the survey technique. In this context, theoretical knowledge is presented and findings obtained from the survey are presented.

Keywords: Regional Courts of Justice, Personnel Motivation, Turkish Public Administration, Productivity

\title{
Giriş
}

İnsan emeğinin üretim sürecine dahil edildiği alanlardan biri de işlevsel olarak bir kamu hizmeti niteliğindeki yargı hizmetleridir. Adaletin tesisine yönelik ana çerçeveyi belirleyen 1982 tarihli Türkiye Cumhuriyeti Anayasasına göre; yargı yetkisi, Türk Milleti adına bağımsız ve tarafsız mahkemelerce kullanılmakta, kanuna ve hukuka uygun olarak vicdanı kanaatlerine göre hüküm veren hâkimler ve savcılar eliyle adalet tecelli ettirilmektedir. Yargının iş yükü dikkate alındığında birçok kamu sektöründen farklı olarak bir yoğunluk ilk başta dikkati çekmektedir. $\mathrm{Bu}$ iş yoğunluğu kaçınılmaz olarak yargısal süreçlerin hantallığından yakınmaları da beraberinde getirmektedir. Yargı süreçlerinin uzun zamana yayılmasının birçok nedeni olduğu düşünülmektedir. Çalışma açısından hedeflenen amaç, yargı süreçlerinin hızlandırılması hedefine katkı sunması amacıyla daha açık bir ifadeyle motivasyon uygulamalarındaki temel amaçlardan birinin personel verimliliğini artırmak olduğu kabulünden hareketle yargıda görevli hâkim ve savcı dışındaki personellerin motivasyon ve verimliliğe ilişkin algılarının tespiti ile yargı özelinde motivasyonun verimlilik üzerinde etkili olup olmadığını, etkili ise boyutunu ve gücünü, etkili değil ise nedenlerini tespit etmektir. Bu amaç doğrultusunda hâkimler ve savcılar dışında Erzurum Bölge Adliye Mahkemesi'nde görev yapmakta çalışanların motivasyon ve verimliliğe ilişkin algılarının tespiti amacıyla anket yöntemiyle veriler toplanmış, elde edilen bulgular istatistiksel olarak yorumlanarak amaç doğrultusunda çıkarımlar yapılmaya çalışılmıştır.

\section{Motivasyonun Tanımı ve Önemi}

Motivasyon kelimesi, Latince kökenli olup Latince'de "Movere” yani harekete geçirme anlamı taşımaktadır (Barlı, 2015, s. 195). Türkçe'de ise güdü, saik veya harekete geçiren olarak karşılık bulur (Eren, 2013, s. 201). Motivasyon, “insanı harekete geçiren ve hareketlerinin yönlerini 
belirleyen, onların, düşünceleri, umutları, inançları, kısaca arzu; ihtiyaç ve korkularıdır" (Fındıkçı, 2000, s.373).

Motivasyon tanımlarındaki ortak nokta, öncelikle bir hedef ya da amacın varlığı, bu hedefe ya da amaca ulaşma noktasındaki isteklilik ile bu hedef ya da amaca ulaşma gayesiyle harekete geçme ya da davranış gösterme şeklinde, sürekli bir döngü halindeki sürecin varlığıdır (Ateş vd. 2012, ss. 147-162).

Örgütler açısından, hedef ya da amaca ulaşma noktasında çalışanları istekli hale getirme ve onları bu yönde teşvik etme arzusu motivasyon kavramını gündeme getirmektedir. Ancak motivasyon sürecinin tam olarak sentezlenebilmesi için çalışanları belli bir şekilde davranmaya iten içsel ya da dışsal faktörlerin irdelenmesi, çalışanların amaçları ve davranışlarının belirlenen hedef ya da amaca ulaşma açısından sürdürülebilir olmasına ilişkin faktörlerin de araştırılması kaçınılmaz kılmaktadır (Sabuncuoğlu ve Vergiliel Tüz, 2016, s. 97).

Motivasyonun en önemli özelliklerinden birisi, bireylerin kişilik yapılarının, istek ve arzularının, ihtiyaç ve motivasyonlarının bireysel farklllık göstermesidir. $\mathrm{Bu}$ nedenle belirlenmiş hedef ya da amaçlara ulaşma idealine doğru her bireyi isteklendirmek ve harekete geçirmek, kısaca motive etmek amacıyla herkes için geçerli olacak bir takım ölçütlerin belirlenmesi çok zor bir iştir. Çünkü her bireyin arzuları, ihtiyaçları ve ruh hali sürekli değişkenlik göstermektedir. Çalışanlar açısından motivasyon, üretken, aktif, performansı yüksek, verimli gibi bireysel çıtıkları güçlendirir (Güngör, 2011, s. 1512). Çalışanların ekonomik ve sosyal ihtiyaçlarını giderebilmelerine, bireysel gelişimlerini güçlendirmelerine, yaratıclıklarını ortaya koyabilmelerine, bir gruba ait olmayı ve grup ekseninde ortak hedefler için çalışma ve çaba gösterebilmelerine olanak sağlar. Kurumlar açısından ise, çalışanların etkin, verimli çalışmaları sonucu kurumun, öte yandan toplumsal ve ekonomik koşullarının, refah seviyesinin yükseltilmesine dönük çalışma isteği açısından rekabet ortamına zemin hazırlamaya olanak sağlayabilecektir (Sabuncuoğlu ve Vergiliel Tüz, 2016, s. 98; Şimşek vd., 2003, ss. 130133).

Çalı̧anlara ve kurumlara birçok açıdan fayda sağlayan motivasyon, sosyal bir varlık olan insanın nerede, ne zaman, nasıl hareket edeceğinin, ihtiyaç ve beklentilerinin neler olacağının değişkenlik göstermesi nedeniyle sürekli araştırmaların güncel konusu haline gelmiştir. Bu farklılıklar göz ardı edilmeksizin geliştirilen teoriler iki ana başlık altında toplanmaktadır. $\mathrm{Bu}$ teori gruplarının ilki içsel faktörlere önem veren kapsam teorileri, ikincisi ise dışsal faktörlere ağırlık veren süreç teorileridir (Koçel, 2001, s. 510).

Kapsam teorileri grubunda A. Maslow' un geliştirdiği ihtiyaçlar hiyerarşisi teorisi, F.Herzberg' in geliştirdiği çift faktör teorisi, David McClelland'ın geliştirdiği başarma ihtiyacı teorisi ve C.Alderfer'in geliştirdiği ERG teorileri (Deniz, 2005, s.143-149), süreç teorileri grubunda ise; V.H. Vroom'un geliştirdiği beklenti teorisi, Lawler - Porter tarafından geliştirilen beklenti teorisi, B. F. Skinner'in geliştirdiği davranış şartlandırma teorisi ile Adams'ın geliştirdiği eşitlik teorileri yer almaktadır (Eren, 2004, ss. 532-545). 
Yukarıda sıralanan bir çok teorinin temel aldığı, motivasyonda geçerliliği genelde kabul gören ve motivasyon uygulamalarına yön veren özendirici araçlar ise; ekonomik, psiko-sosyal, örgütsel ve yönetsel faktörler başlığ 1 altında toplanmak üzere üç grupta incelenmektedir (Kuşluvan, 1999, s.57., Sabuncuoğlu ve Vergiliel Tüz, 2016, ss.118-119).

\section{Verimlilik Kavramı}

Motivasyon uygulamalarıyla elde edilmek istenen birçok sonuç vardır. Bu sonuçlar arasında motivasyon uygulamalarıyla ulaşılmak istenen hedeflerden biri de verimliliktir. Kavramsal olarak verimlilik "kaynakların ürüne dönüşebilirlik düzeyini yansıtmaktadır” (Korkmaz, 1997, s. 3). Verimlilik, çeşitli mal ve hizmetlerin üretiminde yer alan kaynakların etken bir şekilde kullanımıdır (Deligöz ve Güzel, 2016, s. 446). Başka bir tanımla "verimlilik, eldeki kaynaklarla en çok üretimi gerçekleştirme uğraşısıdır” (Doğan ve Aydın, 1991, s.9).

Üretimde kullanılan malzeme, iş gücü, sermaye, enerji vb. girdilerin mal ya da hizmet niteliğindeki çıtılara dönüşmesi verimlilik olarak ifade edilir. En az malzeme, en az iş gücü, minimum sermaye ile daha çok mal ya da hizmet üretebiliyor ise, verimlilik yüksek olarak nitelendirilir (Binbaşığlu, 1992, s.42). Verimlilik aynı zamanda elde edilen mal ya da hizmet çıtılarıyla, bu sonuçları elde etmek için harcanan zaman arasındaki bağı da içerir (Ekinci, 2008, ss. 175-185).

Günümüzde verimlilik ülkelerin kalkınma göstergelerinden biridir. Kalkınma düzeyinin yükseltilmesi hedefine ulaşmada ise var olan kaynakları en faydalı biçimde kullanıp üretimi artırmak amaçlandığından verimlilik çok önemli bir hedef olarak ön plana çıkmaktadır (Aydın, 1999, s.1).

\section{Verimliliği Etkileyen Faktörler}

Verimlilik faktörlerini iki ana başlık altında incelemek mümkündür (Propenko, 1992, s. 56).

- Kontrol Edilebilmesi Mümkün Olan “İçsel” Verimlilik Faktörleri

- Kontrol Edilebilmesi Mümkün Olmayan “Dışsal” Verimlilik Faktörleri

İçsel faktörler işletmenin kontrolü altında iken, dışsal faktörler işletmenin kontrolü dışındadır. Örneğin hükümet politikaları, vergi reformları, yasal değişiklikler dışsal verimlilik faktörlerine örnek oluştururken, ürün, üretim teknolojileri, hammadde ya da iş gücü farklılaştırmaları içsel verimlilik faktörlerine örnek olarak gösterilebilir (Tekeli, 2011, s. 15).

Konumuz açısından değerlendirildiğinde, kamunun verimliliği etkileyen faktörlerin içsel ve dışsal nitelikte olduğu ifade edilebilir.

\section{Verimlilik Kavramı ve Motivasyon iliş̧kisi}

Motivasyonun en önemli amaçlarından birisi de verimliliktir. Verimlilik "En az girdi ile en yüksek çıktıyı" elde etmektir (Mott, 1972, s. 17). Ancak kişiler motive edilebildiği ölçüde verimlilik yükselecektir (Akdemir, 2003, s. 78). Verimliliğe ilişkin bir araştırma sonucuna göre, 
kurum amaçlarına ulaştığında, çalışanların da kendi amaçlarına ulaştığına inanmaları halinde çalışanın motivasyonunun gerçekleşeceği ve bunun da hizmette kaliteyi artırarak elde edilmek istenen verimlilik oranına ulaşılmasına katkı sağlayacağı belirtilmektedir (Uçkun ve Pelit, 2003, ss. 49-54). Diğer bir araştırma ise; çalışanların çalışma düzenlerinin iyileştirilmesiyle birlikte çalışanların mutluluğunun sağlandığı ve bunun da etkin bir motive ve verimlilik sağladığı belirtmektedir (Doğan, 2003, ss. 4-2). Çalışanları mutlu eden faktörler tespit edildiğinde ve bu faktörler aracılığıyla çalışanın emeğinin kurum amacına hizmet edecek şekilde yönlendirilmesi sonucunda üretim veya hizmetlerde verimlilik gerçekleşecektir (Abac1, 6-7 Ekim 2015, s. 148).

Çalışanların motive edilmelerindeki denge ise çalışanlar ile kurum amaçlarının örtüştüğü oranda gerçekleşebilir (Erkut, 1992, ss. 15-16). Bu örtüşmenin sağlanabildiği ölçüde motivasyon ile verimlilik arasındaki bağ ortaya çıkacaktır. Bu amaca ulaşmada çalışanların motivasyon durumları göz önüne alınıp, yapılacak araştırmalar sonucunda motivasyon faktörlerinin etkin bir şekilde belirlenip uygulamaya konulması gerekir (Abacı, 6-7 Ekim 2015, s.150). Çalışanların işinden duyduğu hoşnutluk artırılarak motive edilmeleri, işlerinde gösterecekleri çaba ve başarıyı artıracaktır. Sonuçta motive olan çalışan gücü, örgütün amacına ulaşmadaki başarı düzeyini yükseltecek ve kaynaklardan en verimli şekilde yararlanılmasına olanak sağlayacaktır (Eroğlu, 2015, ss. 453-454).

\section{Kamu Yönetiminde Verimlilik}

Günümüzde verimliliği artırmaya yönelen çalışmaların birçoğunda yetki alanı, performans yönetimi, kalite yönetimi ve yetki devri gibi başlıklar öne çıkmaktadır. Benzer şekilde bu başlıklar kamu kurumlarının da problemlerini açıklamaya yardımcı olmaktadır. Ancak bu yöntemlerin birçoğu özel sektöre yönelik olduğundan kamu kurumlarında uygulama alanı bulması özel sektöre göre daha zordur. Çünkü kamu kurumlarının yapısal farklılıkları ve çevresi özel sektörlerden oldukça bağımsızdır ve özel sektörlerde uygulama alanı bulan her yöntemin kamu yönetimine de kolayca adapte edilebileceği ve başarıyla uygulanabileceğini ifade etmek güçtür. Bu güçlüğü aşabilmek adına kamunun da verimliliği ön planda tutması gerekir. Bu noktada ise verimliliğin önündeki engellerin neler olduğu önem arz eder (Öztürk, 2004, s. 1).

Öztürk'e göre kamu sektöründe verimliliğin önündeki engeller; bu gruplar içindeki unsurlardan birçoğu birden fazla engel sınıfının içinde yer alsa da genel bir ayrım olarak üç ana grup altında ele alınabilir. Bunlardan ilki özel sektörden farklı olarak kamu yönetimindeki verimlilik arayışlarını engelleyen unsurları içinde barındıran çevresel engellerdir. İkinci olarak kamu sektörünün yapısal niteliğinden kaynaklanan örgütsel engeller, son olarak bireysel nitelikteki personel engelleridir (Öztürk, 2004, s. 4).

\section{Araştırmanın Metodolojisi}

\section{Araştırmanın Amacı ve Konusu}

Araştırma, insanı harekete geçiren, onun davranışlarını yönlendiren motivasyonun Türk Kamu yönetimindeki personel verimliliği üzerine etkilerinin araştırılması amacıyla Erzurum Bölge Adliye Mahkemesi özelinde yapılmıştır. Literatürde motivasyon faktörlerinin belirlenmesine 
ilişkin bir çok çalışma mevcuttur (Mottaz, 1985; Brislin vd., 2005; Mahaney ve Lederer, 2006). Ancak insanı harekete geçiren motivasyon faktörlerinin verimlilik üzerine etkilerine yönelik yargı özelinde literatür eksikliği bulunmaktadır. Bu doğrultuda araştırmanın konusu, Erzurum Bölge Adliye Mahkemesi’nde görev yapmakta olan hâkim ve Cumhuriyet savcıları dışındaki kamu çalışanlarıdır.

\section{Araştırmanın Evreni ve Örneklemi}

$\mathrm{Bu}$ araştırmanın ana evrenini Türk kamu yönetiminde çalışan kamu görevlileri oluşturmaktadır. Ancak çalışma, Erzurum Bölge Adliye Mahkemesi'nde görev yapmakta olan hâkim ve Cumhuriyet savcıları dışında görev yapan personeller ile sınırlandırılmıştır. Bunun nedeni, yargı hizmetlerinin diğer kamu hizmetlerine nazaran daha çok önem arz etmesi, bu alanda sunulan hizmetlerden kaynaklanan toplumsal yakınmaların sürekliliği, bu yakınmalara yönelik çözüm arayışlarının güncelliğini koruması, tüm kamu kurumlarında görev yapan çalışan sayısının büyüklüğü karşısında; gerek maliyet gerekse zaman kaynaklı imkânsızlıklar ile yargı alanında daha önce bu nitelikteki bir çalışmanın bulunmamasıdır. Bu nedenle çalışma ülke geneli veya diğer kamu kurumları için genellenemez.

Çalışmanın örneklemini oluşturan Erzurum Bölge Adliye Mahkemesi’nde 1 idari işler müdürü, 15 yazı işleri müdürü, 58 zabıt kâtibi, 16 mübaşir, 4 şoför, 3 teknisyen ve 9 hizmetli çalışmaktadır. Araştırmanın amacı, türü ve maliyeti dikkate alınarak hipotezlerle ilgili bilgilerin ana kitleye göre türdeş (homojen) olması nedeniyle basit tesadüfi örnekleme yöntemi kullanılmıştır.

\section{Araştırmanın Örneklem Büyüklüğü}

Erzurum Bölge Adliye Mahkemesinde 106 personel bulunmaktadır. Araştırma anketi 106 kişilik personel grubunun tamamına uygulanmıştır. Yeterli bir örneklem, güvenilir sonuçlar sağlayacak kadar eleman kapsayan örneklemdir (Young, 1968, s. 324). Araştırmanın örneklem büyüklüğü 76,753 olup bu doğrultuda, 106 katılımcı ile güvenilir sonuç sağlayacak kadar eleman kapsayan, yeterli bir örneklem elde edilmiştir (Yazıcıoğlu ve Erdoğan, 2004, ss. 49-50).

\section{Araştirmanin Yöntemi}

Araştırmada, bir olgu ile ilgili olarak toplanan nicel verilen o olguyu yeterince ölçmeyip açıklayamadığı ve bu hususa ilişkin derinlemesine bilgi sunmadığı eleştirileri de dikkate alınarak (İslamoğlu, A. H., 2011, ss.186-188; Şimşek ve Yıldırım, 2005, s.37) olayın bütünlüğünü göz önünde bulundurmaya olanak sağlayan, araştırma konusunu bütüncül bir yaklaşımla ele almaya imkan veren nitel araştırma yöntemi kullanılmıştır.

Araştırmanın hipotezlerini test etmek üzere sistematik bir biçimde bilgilerin toplanması amacıyla, Erzurum Bölge Adliye Mahkemesi'nde görev yapmakta olan hâkim ve savcılar dışındaki personelin algılarını ölçmek üzere yüz yüze anket uygulanmıştır.

Hazırlanan anket üç bölümden oluşturulmuştur. Birinci bölümde ankete katılan personellerin demografik özellikleri yer almaktadır. İkinci bölümde motivasyon araçlarının çalışanların 
motivasyonu üzerindeki etkisini ölçmeye yönelik olarak Mottaz (Mottaz, F., 1985, s. 336), Brislin (Brislin vd., 2005), Mahaney ve Lederer'in (Mahaney ve Lederer, 2006, ss. 42-54) çalışmalarında kullandıkları ölçeklerin temel alındığı anket sorularından (Dündar vd., 2007), çalışanların verimliliğe ilişkin algılarının ölçülmesinde ise López-Ortega ve Saloma-Velazquez (Eugenio López-Ortega, Rita Saloma-Velazquez, 2002) tarafından geliştirilen ölçek temel alınarak hazırlanmış olan anket sorularından yararlanılmıştır (Göktepe, 2010, ss. 122-124).

\section{Araştırmanın Hipotezleri}

Araştırmanın hipotezleri şu şekildedir.

$\mathrm{H}_{1}$ : Motivasyon, verimlilik üzerinde pozitif yönde etkilidir.

$\mathrm{H}_{2}$ : Motivasyona ilişkin algı üzerinde demografik özellikler açısından anlamlı bir farklılık yoktur.

$\mathrm{H}_{\text {2a: }}$ Motivasyona ilişkin algı; cinsiyete,

$\mathrm{H}_{2 \mathrm{~b}}$ : Yaşa,

$\mathrm{H}_{2 c}$ : Eğitim durumuna,

$\mathrm{H}_{2 \mathrm{~d}}$ : Unvana,

$\mathrm{H}_{2 \mathrm{e}}$ : Çalışma süresine göre farklılık göstermemektedir.

$\mathrm{H}_{3}$ : Verimliliğe ilişkin algı üzerinde demografik özellikler açısından anlamlı bir farklılık yoktur.

$\mathrm{H}_{3 a:}$ Verimliliğe ilişkin alg1; cinsiyete,

$\mathrm{H}_{3 \mathrm{~b}}$ : Yaşa,

$\mathrm{H}_{3 c}$ : Eğitim durumuna,

$\mathrm{H}_{3 \mathrm{~d}}$ : Unvana,

$\mathrm{H}_{3 \mathrm{e}}$ : Çalışma süresine göre farklılık göstermemektedir.

$\mathrm{H}_{4}$ : İçsel motivasyona ilişkin algı üzerinde demografik özellikler açısından anlamlı bir farklilık yoktur.

$\mathrm{H}_{\text {4a: }}$ İçsel motivasyona ilişkin alg1; cinsiyete,

$\mathrm{H}_{4 \mathrm{~b}}$ : Yaşa,

$\mathrm{H}_{4 c}$ : Eğitim durumuna,

$\mathrm{H}_{4 \mathrm{~d}}$ : Unvana,

$\mathrm{H}_{4 \mathrm{e}}$ : Çalışma süresine göre farklılık göstermemektedir.

$\mathrm{H}_{5}$ : Dışsal motivasyona ilişkin algı üzerinde demografik özellikler açısından anlamlı bir farklılik yoktur.

$\mathrm{H}_{5 \mathrm{a}}$ Dışsal motivasyona ilişkin algı; cinsiyete,

$\mathrm{H}_{5 \mathrm{~b}}$ : Yaşa,

$\mathrm{H}_{5 c}$ : Eğitim durumuna,

$\mathrm{H}_{5 \mathrm{~d}}$ : Unvana,

$\mathrm{H}_{5 \mathrm{e}}$ : Çalışma süresine göre farklılık göstermemektedir.

$\mathrm{H}_{6}$ : Dişsal motivasyon içsel motivasyona göre verimlilik üzerinde daha etkilidir. 


\section{Verilerin Analiz Yöntemi ve Güvenilirlik Analizi}

Anket soruları beşli Likert ölçeğine göre hazırlamış, her bir soru için verilen cevaplar 1 ile 5 sayıları arasında işaretlenmek üzere düzenlenmiştir. Motivasyon faktörlerine ilişkin sorulara sırasılla "Kesinlikle motive etmez", "Motive etmez", "Kararsızım / Fikrim yok", "Motive eder.", "Kesinlikle motive eder." seçenekleri, verimliliğe ilişkin sorulara sırasıyla "Kesinlikle katılmıyorum", "Katılmıyorum", "Kararsızım / Fikrim yok", "Katılıyorum.”, "Kesinlikle katılıyorum." seçeneklerinin katılıcımlar tarafından kendilerine en uygun olan cevaba göre işaretlenmesi istenmiştir. Beşli Likert ölçeğinde aritmetik ortalamanın değerine göre 1 cevabına yaklaşan katılımlar düşük katılım, 5 değerine yaklaşan katılımlar yüksek katılım olarak değerlendirilmiştir.

Araştırmadan elde edilen veriler SPSS 22.0 paket programı ile bilgisayar ortamına aktarılıp toplanan veriler yorumlanmıştır.

Anket sorularıyla bir araya getirilmiş ifadelerin kendi içinde tutarlı olup olmadığı, diğer bir deyişle aynı yapıyı ölçüp ölçmediğinin tespiti amacıyla güvenilirlik analizi yapılmıştır (Yaşlıoğlu, 2017, s.78). İç tutarlılığın (güvenilirliğin) ölçümünde Cronbach’s Alpha katsayısı kullanılmıştır. Tablo 1'de güvenilirlik analizi sonuçları gösterilmiştir.

Tablo 1. Motivasyon ve Verimlilik Sorularına İlişkin Güvenilirlik Analizi Sonuçları

\begin{tabular}{|c|c|c|}
\hline & Soru Sayısı & Crobach's Alpha Katsayıları \\
\hline Motivasyon & 12 & 0,858 \\
\hline İçsel Motivasyon Faktörleri & 6 & 0,720 \\
\hline Dişsal Motivasyon Faktörleri & 6 & 0,799 \\
\hline Verimlilik & 8 & 0,716 \\
\hline & 20 & 0,852 \\
\hline
\end{tabular}

Tablo 1'de görüleceği üzere motivasyon faktörlerine ilişkin güvenilirlik analizinin Cronbach's Alpha değeri 0,858 , verimliliğe ilişkin sorularda ise 0,716 olarak bulunmuştur. Motivasyon faktörlerinin alt boyutlarından içsel faktörlere ilişkin katsayı 0,720, dışsal motivasyon faktörlere ilişkin 0,799'tir. Dolayısıyla tüm değişkenlerin güvenilirlikleri kabul edilebilir düzey olan 0,70'lik Cronbach's Alpha düzeyinin üzerindedir ve güvenilir olduğu kabul edilmiştir (Durmuş vd. 2016, s. 89).

\section{Araştırmanın Modeli}

Araştırmada bağımlı değişken verimliliktir. Bağımsız değişken motivasyon faktörleridir ve 2 alt faktörden oluşturmaktadır. Araştırma modeli Şekil 9‘daki gibidir. 


\section{Motivasyon $\Rightarrow$ Verimlilik}

Şekil 1. Araştırmanın Modeli

\section{Faktör Analizleri}

Anket sorularının oluşturulmasında yararlanılan ölçeklerin, mevcut çalışmamızda kullanıldığında orijinal faktör yapısına uyup uymadığının, uyuyor ise ne derece uyduğunun belirlenmesi amacıyla "Doğrulayıcı Faktör Analizi” yapılmıştır (Yaşlığlu, 2017, ss.78-79).

Faktör analizi yapmak için örneklemin yeterli olup olmadığına ilişkin Kaiser-Mayer-Olkin (KMO) testi uygulanmış, motivasyon ölçeğine ilişkin KMO testinde bulunan 0,801 değeri ile verimlilik ölçeğine ilişkin KMO testinde bulunan 0,654 değerinin, örneklemin yeterli olduğunu gösteren 0,60 değerinden büyük olduğu görülmüştür.

Değişkenler arasında faktör analizi yapılabilecek güçte bir ilişki olup olmadığını tespit edebilmek amacıyla Barletts testi uygulanmış, sig. değeri 0,05’ten küçük olup motivasyon ölçeğinin değişkenleri ve verimlilik ölçeğinin değişkenlerinin faktör analizi yapılabilecek kadar aralarında ilişki olduğu görülmüştür (İslamoğlu, 2011, s.244).

Motivasyona ilişkin anket soruları iki alt faktörden oluşmakta, bu çalışmada motivasyonun sadece içsel ve dışsal boyutları üzerinde durulmaktadır. İçsel motivasyon herhangi bir zorlama olmaksızın haz duyma, hoşlanma veya bir davranışın kazanılması gibi içe yönelik hareketleri kapsar. Dışsal motivasyon ise ödül alma, rekabet etme, cezadan kaçınma gibi sonuçları hedefleyen davranışları ifade eder.

Anket sorularından 1-12 arasındaki sorular motivasyona ilişkin algıyı ölçmek amacıyla kullanılmış olup ilk altı soru içsel, ikinci altı soru dışsal motivasyon faktörlerine ilişkindir. Faktör analizine ilişkin sonuçlar Tablo 2'de gösterilmiştir. 
Tablo 2. Motivasyon Boyutları ve Verimliliğe İlişkin Faktör Analizleri

\begin{tabular}{|c|c|c|c|}
\hline & \multicolumn{3}{|c|}{ Faktör Yükleri } \\
\hline Motivasyon & $\begin{array}{l}\text { Faktör } 1 \\
\text { (İçsel) }\end{array}$ & $\begin{array}{l}\text { Faktör } 2 \\
\text { (Dışsal) }\end{array}$ & Faktör 3 \\
\hline \multicolumn{4}{|l|}{ Motivasyon Faktörleri } \\
\hline $\begin{array}{l}\text { Yaptığım işte başarılı olmam } \\
\text { Yaptığım iş ile ilgili sorumluluk verilmesi } \\
\text { Yaptığım işin yapılmaya değer bir iş olduğuna inanmam } \\
\text { Yöneticilerin onurlandıran tavır ve davranışları } \\
\text { Yaptığım iş ile ilgili bir konuda karar verebilmem } \\
\text { Çalışma ortamımda fiziksel şartların uygunluğu }\end{array}$ & $\begin{array}{l}0,794 \\
0,645 \\
0,727 \\
0,646 \\
0,675 \\
0,719\end{array}$ & & \\
\hline \multicolumn{4}{|l|}{ Motivasyon Faktörleri } \\
\hline $\begin{array}{l}\text { İşimde terfi imkânımın olması } \\
\text { Başarımdan dolayı ödüllendirilmem } \\
\text { Konularında uzman olan kişiler tarafindan toplantı, } \\
\text { seminer, konferans vb. faaliyetlerle eğitim sağlanması } \\
\text { İş yerindeki araç ve gereçlerin yeterli olması } \\
\text { Yaptığım işten aldığım ücretin miktarı } \\
\text { Yemek, çay - kahve gibi imkânların ücretsiz olarak } \\
\text { sağlanması } \\
\text { KMO } \\
\text { Bartlett's Test Of Sphericity } \quad \text { Approx-Chi-Square } \\
\text { Sig. }\end{array}$ & $\begin{array}{r}0,801 \\
517,149 \\
, 000 \\
\end{array}$ & $\begin{array}{l}0,684 \\
0,726 \\
0,787 \\
\\
0,804 \\
0,380 \\
0,602\end{array}$ & \\
\hline \multicolumn{4}{|l|}{ Verimlilik } \\
\hline $\begin{array}{l}\text { İşimi severek yaparım. } \\
\text { Iş̧imi yaparken, israfi önlemeye çalışırım. } \\
\text { Mesleki gelişimim için, bilimsel etkinlikleri (kongre, kurs, } \\
\text { seminer vb.) takip ederim. } \\
\text { Aşırı iş yoğunluğu içerisinde çalışmam, hata yapmamı } \\
\text { kolaylaştırır. } \\
\text { Bu kurumda ilerleme/yükselme fırsatlarının sınırlı olması, } \\
\text { çalışma isteğimi azaltır. } \\
\text { Çalıştığım kurumda iş güvencemin olmamasından huzursuz } \\
\text { olurum. } \\
\text { Çalıştığım birimde yöneticiler, çalışanlar için huzurlu bir } \\
\text { çalışma ortamı sağlamaya gayret eder. } \\
\text { Çalıştığım birimin fiziki ve teknik alt yapısındaki } \\
\text { eksikliklerin (1sınma, aydı̈latma, asansörler, telefon vb.) } \\
\text { işimi aksattığını düşünürüm. } \\
\text { KMO } \\
\text { Bartlett's Test Of Sphericity }\end{array}$ & $\begin{array}{r}0,654 \\
133,394 \\
, 000\end{array}$ & & $\begin{array}{l}0,666 \\
0,908 \\
0,789 \\
0,685 \\
0,796 \\
0,721 \\
0,690 \\
0,544\end{array}$ \\
\hline
\end{tabular}

\section{Araştırmaya iliş̧kin Demografik Veriler}

Demografik değişkenler açısından unvan değişkeninde idari işler müdürü grubunda 1 gözlem olması nedeniyle bu gözlem yazı işleri müdürü grubuna dâhil edilmiştir. $\mathrm{Bu}$ husus doğrultusunda anket çalışmasının birinci bölümünü oluşturan demografik özelliklere ilişkin tablo aşağıda sunulmuştur. 
Tablo 3. Araştırma Örneklemine İlişkin Demografik Veriler

\begin{tabular}{|c|c|c|c|}
\hline & Cinsiyet & Frekans & Yüzde (\%) \\
\hline & Erkek & 76 & 71,7 \\
\hline . & Kadın & 30 & 28,3 \\
\hline ت̈ & Toplam & 106 & 100 \\
\hline & $18-25$ & 12 & 11,3 \\
\hline $\bar{\Xi}$ & $25-33$ & 20 & 18,9 \\
\hline ָี⿻ & $33-41$ & 61 & 57,5 \\
\hline$\approx$ & 41 ve üzeri & 13 & 12,3 \\
\hline & Toplam & 106 & 100 \\
\hline & Lise & 14 & 13,2 \\
\hline$\underline{\mathbf{E}}$ & Ön lisans & 22 & 20,8 \\
\hline 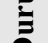 & Lisans & 66 & 62,3 \\
\hline $\bar{\Xi}$ & Master / Doktora & 4 & 3,7 \\
\hline$\sum_{0.0}$ & Toplam & 106 & 100 \\
\hline & 2 yıldan az & 9 & 8,5 \\
\hline & $2-5$ y1l aras1 & 9 & 8,5 \\
\hline & $5-10$ y1l arası & 40 & 37,7 \\
\hline ֻ & $10-15$ y1l arası & 34 & 32,1 \\
\hline$\pi$ & $15-25$ y1l aras 1 & 12 & 11,3 \\
\hline$\stackrel{\bar{m}}{=}$ & 25 y1l ve üzeri & 2 & 1,9 \\
\hline ש & Toplam & 106 & 100 \\
\hline & Yazı ve İdari İşler Müdürü & 16 & 15,1 \\
\hline & Zabit Kâtibi & 58 & 54,7 \\
\hline & Mübaşir & 16 & 15,1 \\
\hline$\underline{E}$ & Teknisyen & 3 & 2,8 \\
\hline$\stackrel{\sum}{\Xi}$ & Şoför & 4 & 3,8 \\
\hline & Hizmetli & 9 & 8,5 \\
\hline & Toplam & 106 & 100 \\
\hline
\end{tabular}

Cinsiyet dağılımları ele alındığında katılımcıların büyük çoğunluğunun $\% \quad 71,7$ ile erkeklerden, \% 28,3 ile kadınlardan oluştuğu görülmektedir.

Yaş dağılımları ele alındığında katılımcıların büyük çoğunluğu \% 57,5 ile 33-41 yaş grubunda, ikinci olarak \% 18,9 ile 25-33 yaş grubunda, üçüncü olarak \% 12,3 ile 41 yaş ve üzeri, son olarak \% 11,3 ile 18-25 yaş grubundaki çalışanlardan oluştuğu görülmektedir.

Eğitim durumları dağılımı ele alındığında katılımcıların büyük çoğunluğunun \% 62,3 ile lisans mezunlarından, ikinci olarak \% 20,8 ile ön lisans mezunlarından, \% 13,2 ile lise mezunlarından, \% 3,7 ile master / doktora mezunlarından oluştuğu, ortaokul mezunu bir çalışan olmadığ 1 görülmektedir. 
Çalışma süreleri dağılımları ele alındığında katılımcıların büyük çoğunluğunun \% 37,7 ile 5-10 yıl arası, ikinci olarak \% 32,1 ile 10-15 yıl arası, \% 8,5 ile 2 yıldan az ve 2-5 yıl arası, \% 11,3 ile 15-25 yıl arası, \% 1,9 ile 25 yıl ve üzeri çalışma sürelerine sahip oldukları görülmektedir.

Unvan dağılımları ele alındığında katılımcıların büyük çoğunluğunun \% 54,7 ile zabıt kâtiplerinden, ikinci olarak \% 15,1 ile idari işler müdürü ve yazı işleri müdürlerinden, \% 15,1 ile mübaşirlerden, \% 8,5 ile hizmetlilerden, \% 3,8 ile şoförlerden ve \% 2,8 ile teknisyenlerden oluştuğu görülmektedir.

\section{Bulguların Analizi ve Mevcut Literatürle ilişkisi}

Çalışan motivasyonu ile verimliliğini etkileyen faktörlere ilişkin literatürde birçok araştırma yapılmıştır. Bu araştırmalara ilişkin bir takım bulgular aşağıda sıralanmaktadır.

Özel sektörde faaliyet gösteren bir gıda işletmesine ilişkin işgören verimliliğini etkileyen faktörlerin incelenmesine yönelik bir alan araştırmasında, ücretin, işletme içerisindeki sağlıklı iletişimin ve fiziksel koşulların uygunluğunun verimliliği etkileyen unsurlar olduğu tespit edilmiştir (Yumuşak, 2008, ss. 241-251). Bir kamu kurumu niteliğinde olan Antalya Havalimanı çalışanları arasında bir örnek olay araştırması olarak işletmelerde motivasyon ve verimlilik ilişkisine yönelik yapılan araştırmada; kurum için iletişimin önemi, ücret ve fiziksel koşulların iyileştirilmesi, iş yapılırken kullanılan malzeme, ekipman ve teknolojinin motivasyonu artıracağı ve işgörenlerin daha verimli çalışmalarını sağlayabileceği ifade edilmiştir (Pekel, 2001, ss.202-209).

İçsel ve dışsal motivasyon araçlarının işgörenlerin motivasyonları üzerine etkisine yönelik termal otel çalışanlarıyla gerçekleştirilen bir amprik çalışmada, içsel ve dişsal motivasyon araçlarının işgörenlerin motivasyonu üzerinde etkili olduğu, içsel motivasyon araçlarının dışsal motivasyon araçlarına göre motivasyon üzerinde daha etkili olduğu belirtilmiştir (Dündar vd., 2007, s.113). Motivasyon araçlarından yönetime katılmanın işgörenlerin daha verimli ve etkin çalışmalarını sağlayacağı, motivasyona etki eden faktörlerin yarı oranla ekonomik faktörler, diğer yarı oranla da psiko-sosyal ve örgütsel faktörler olduğu ifade edilmiştir (Karakaş, 2010, ss.97-100).

Herzberg'in çift faktör teorisinin uygulandığı kamu kurumlarında görev yapan öğretmenlere yönelik motivasyon faktörlerinin araştırıldığ özelliklere göre farklılık göstermediği sonucu tespit edilmiştir (Ateş vd., 2012).

Literatürden örneklenen bu araştırmalardan elde edilen sonuçlara genel olarak bakıldığında motivasyon araçlarının motivasyon üzerinde etkili olduğu, motivasyonun da verimliliği etkilediği tespit edilmektedir. Ancak yargı alanına yönelik bu konuda bir çalışma bulunmadığından genel olarak özetlenen bulguların yargı alanına ilişkin yansıması bulgular ışığında değerlendirilecek, mevcut literatür sonuçlarıyla farklılık gösterip göstermediği belirlenmeye çalışılmaktadır. 


\section{Araştırma Modelinin Test Edilmesi}

Ankete katılan bireylerin anket formlarına doğru yanıtlar verdikleri varsayımına dayanılarak motivasyon faktörlerinin verimlilik üzerine etkileri Regresyon Analizi ile test edilmiştir. Basit regresyon yönetimi ile elde edilen sonuçlar tabloda gösterilmiştir.

Tablo 4. Motivasyon ve verimlilik arasındaki ilişki

\begin{tabular}{|c|c|c|c|c|c|}
\hline \multirow{2}{*}{$\begin{array}{l}\text { Bağımlı Değişken } \\
\text { Verimlilik }\end{array}$} & $\overline{\mathbf{R}}$ & $\overline{\mathbf{R}^{2}}$ & Düzeltilmiş $\mathbf{R}^{2}$ & \multicolumn{2}{|c|}{$\begin{array}{c}\text { Tahminin Standart } \\
\text { Hatası }\end{array}$} \\
\hline & 0,545 & 0,296 & 0,290 & \multicolumn{2}{|c|}{0,46114} \\
\hline Anova & $\begin{array}{c}\text { Kareler } \\
\text { Toplamı }\end{array}$ & $\begin{array}{r}\text { Serbestlik } \\
\text { Derecesi }\end{array}$ & Kareler Ortalaması & F Değeri & $\mathbf{P}$ \\
\hline Regresyon & 9,320 & 1 & 9,320 & 43,829 & 0,00 \\
\hline Artıklar & 22,116 & 104 & 0,213 & & \\
\hline Toplam & 31,436 & 105 & & & \\
\hline \multirow{2}{*}{$\begin{array}{l}\text { Bağımsız Değişken } \\
\text { Motivasyon }\end{array}$} & \multicolumn{2}{|c|}{$\begin{array}{c}\text { Standartlaştırılmamış } \\
\text { Katsayılar }\end{array}$} & $\begin{array}{c}\text { Standartlaştırılmış } \\
\text { Katsayılar }\end{array}$ & \multirow[b]{2}{*}{ t Değerleri } & \multirow[b]{2}{*}{$\mathbf{P}$} \\
\hline & $\bar{B}$ & $\begin{array}{c}\text { Standart } \\
\text { Hata }\end{array}$ & Beta & & \\
\hline Sabit & 1,255 & 0,409 & & 3,068 & 0,03 \\
\hline Motivasyon & 0,625 & 0,094 & 0,545 & 6,620 & 0,00 \\
\hline
\end{tabular}

$\mathrm{Bu}$ sonuçlar doğrultusunda oluşturulan basit regresyon modeli bir bütün olarak (F,p) 0,05 önem düzeyinde istatistiksel açıdan anlamlı bulunmuş olup kurulan modelin açıklayıcılık gücü \% 29,6'dır. Bu oran ile çalışan verimliliğinin \% 29,6'sı motivasyon faktörleriyle açıklanabilir denilebilir. Model incelendiğinde movitasyon faktörlerinin, verimlilik üzerinde $0,05$ önem düzeyinde anlamlı bir pozitif etkiye sahip olduğu görülmektedir ( $B=0,625 ; p=0,00)$. $\mathrm{Bu}$ sonuç, 0,05 önem düzeyinde motivasyon uygulamalarındaki 1 birimlik artışın verimliliği 0,625 birim artırdı̆̆ uygulamalar arttıkça verimliliğin yükseleceğini ifade etmek mümkündür. Bu sonuçlar ışığında, motivasyon faktörlerinin verimlilik üzerinde pozitif yönde etkili olduğunu öngören $H_{1}$ hipotezi kabul edilmiştir (Tablo 4).

$\mathrm{Bu}$ sonuçlar, daha önce literatür taramasında örneklenen çalışmalarla paralel şekilde motivasyon uygulamalarının verimlilik üzerinde etkili olduğu yönünde bir farklılık göstermediği tespit edilmiştir. 


\section{Demografik Özellikler ile Motivasyona Yönelik Algı Arasındaki Farklılıklara iliş̧kin Anova Analizi Sonuçları}

Tablo 5. Motivasyona ilişkin algının cinsiyet değişkenine göre incelenmesi

\begin{tabular}{|c|c|c|c|c|c|c|c|}
\hline & & $\mathrm{n}$ & Mean & S.D. & $\mathrm{F}$ & $\mathrm{p}$ & Sonuç \\
\hline $\mathrm{H}_{2 \mathrm{a}: K a t 1 l ı m c 1 l a r ı n}$ cinsiyetlerine & Erkek & 76 & 4,2928 & 0,46478 & \multirow[t]{2}{*}{0,370} & \multirow[t]{2}{*}{0,544} & \multirow[t]{2}{*}{ Kabul } \\
\hline $\begin{array}{l}\text { göre içsel motivasyon unsurlarına } \\
\text { ilișkin algılarında farklılık yoktur. }\end{array}$ & Kadın & 30 & 4,3556 & 0,51227 & & & \\
\hline
\end{tabular}

Yapılan analiz sonucunda, $\mathrm{p}>0,05$ olduğu için cinsiyet değişkeni ile motivasyon unsurlarına ilişkin algı arasında anlamlı bir farklılık yoktur. $\mathrm{H}_{2 \mathrm{a}}$ hipotezi bu nedenle kabul edilmiştir (Tablo $5)$.

Tablo 6. Motivasyona ilişkin algının yaş değişkenine göre incelenmesi

\begin{tabular}{|c|c|c|c|c|c|c|c|}
\hline & & $\mathrm{n}$ & Mean & S.D. & $\bar{F}$ & $\mathrm{p}$ & Sonuç \\
\hline \multirow{4}{*}{$\begin{array}{l}\mathrm{H}_{2 b} \text { :Katılımcıların yaşa göre } \\
\text { motivasyon unsurlarına ilişkin } \\
\text { alg1larında farklılı yoktur. }\end{array}$} & $\begin{array}{c}18-25 \\
\text { yas }\end{array}$ & 12 & 4,3819 & 0,35079 & \multirow{4}{*}{0,932} & \multirow{4}{*}{0,428} & \multirow{4}{*}{ Kabu } \\
\hline & $25-33$ & 20 & 4,1542 & 0,51461 & & & \\
\hline & $\begin{array}{c}33-41 \\
\text { yas }\end{array}$ & 61 & 4,3484 & 0,48269 & & & \\
\hline & $\begin{array}{l}41 \mathrm{ve} \\
\text { üzeri }\end{array}$ & 13 & 4,3077 & 0,49111 & & & \\
\hline
\end{tabular}

Yapılan analiz sonucunda, $\mathrm{p}>0,05$ olduğu için yaş değişkeni ile motivasyon unsurlarına ilişkin algı arasında anlamlı bir farklılık yoktur. $\mathrm{H}_{2 \mathrm{~b}}$ hipotezi bu nedenle kabul edilmiştir (Tablo 6).

Tablo 7. Motivasyona ilişkin algının eğitim durumu değişkenine göre incelenmesi

\begin{tabular}{|c|c|c|c|c|c|c|c|}
\hline & & $\mathrm{n}$ & Mean & S.D. & $\bar{F}$ & $\mathrm{p}$ & Sonuç \\
\hline \multirow{4}{*}{$\begin{array}{llr}\text { H2c:Katılımcıların } & \text { eğitim } \\
\text { durumuna göre } & \text { motivasyon } \\
\text { unsurlarına ilişkin } & \text { algılarında } \\
\text { farklılık yoktur. }\end{array}$} & Lise & 14 & 4,3393 & 0,39960 & \multirow{4}{*}{0,042} & \multirow{4}{*}{0,997} & \multirow{4}{*}{ Kabul } \\
\hline & Önlisans & 22 & 4,3258 & 0,48037 & & & \\
\hline & Lisans & 66 & 4,2992 & 0,50594 & & & \\
\hline & $\begin{array}{l}\text { Master / } \\
\text { Doktora }\end{array}$ & 4 & 4,2778 & 0,38490 & & & \\
\hline
\end{tabular}

Yapılan analiz sonucunda, $p>0,05$ olduğu eğitim durumu değişkeni ile motivasyon unsurlarına ilişkin algı arasında anlamlı bir farklılık yoktur. $\mathrm{H}_{2 \mathrm{c}}$ hipotezi bu nedenle kabul edilmiştir (Tablo $7)$. 
Tablo 8. Motivasyona ilişkin algının unvan değişkenine göre incelenmesi

\begin{tabular}{|c|c|c|c|c|c|c|c|}
\hline & & $\mathrm{n}$ & Mean & S.D. & $\mathrm{F}$ & $\mathrm{p}$ & Sonuç \\
\hline \multirow{6}{*}{$\begin{array}{l}\text { H2d:Katılımcıların unvana } \\
\text { göre motivasyon unsurla- } \\
\text { rına ilişkin algılarında } \\
\text { farklılı yoktur. }\end{array}$} & $\begin{array}{c}\text { İdari İşler Yazı } \\
\text { İşleri Müdür }\end{array}$ & 16 & 4,3229 & 0,72831 & \multirow{6}{*}{0,631} & \multirow{6}{*}{0,677} & \multirow{6}{*}{ Kabul } \\
\hline & Z. Katibi & 58 & 4,2888 & 0,44651 & & & \\
\hline & Mübaşir & 16 & 4,4323 & 0,37911 & & & \\
\hline & Teknisyen & 3 & 4,5833 & 0,00000 & & & \\
\hline & Şoför & 4 & 4,1250 & 0,10758 & & & \\
\hline & Hizmetli & 9 & 4,2037 & 0,45474 & & & \\
\hline
\end{tabular}

Yapılan analiz sonucunda, $\mathrm{p}>0,05$ olduğu için unvan değişkeni ile motivasyon unsurlarına ilişkin algı arasında anlamlı bir farklılık yoktur. $\mathrm{H}_{2 \mathrm{~d}}$ hipotezi bu nedenle kabul edilmiştir (Tablo 8).

Tablo 9. Motivasyona ilişkin algının çalışma süreleri değişkenine göre incelenmesi

\begin{tabular}{|c|c|c|c|c|c|c|c|}
\hline & & $\mathrm{n}$ & Mean & S.D. & $\mathrm{F}$ & $\mathrm{p}$ & Sonuç \\
\hline \multirow{6}{*}{$\begin{array}{l}\mathrm{H}_{2 e} \text { :Katılımcıların çalışma sürele- } \\
\text { rine göre motivasyon unsurlarına } \\
\text { ilişkin algılarında farklılık yoktur. }\end{array}$} & $\begin{array}{c}2 \\
\text { y1ldan } \\
\text { az }\end{array}$ & 9 & 4,4444 & 0,34861 & \multirow{6}{*}{0,736} & \multirow{6}{*}{0,598} & \multirow{6}{*}{ Kabul } \\
\hline & $\begin{array}{l}2-5 \\
Y_{1} 1\end{array}$ & 9 & 4,1759 & 0,33964 & & & \\
\hline & $\begin{array}{c}5-10 \\
Y_{11}\end{array}$ & 40 & 4,2938 & 0,38582 & & & \\
\hline & $10-15$ & 34 & 4,3235 & 0,62891 & & & \\
\hline & $15-25$ & 12 & 4,2500 & 0,45644 & & & \\
\hline & $\begin{array}{c}25 \text { y1l } \\
\text { üstü }\end{array}$ & 2 & 4,7917 & ,05893 & & & \\
\hline
\end{tabular}

Yapılan analiz sonucunda, $\mathrm{p}>$ 0,05 olduğu için çalışma süresi değişkeni ile motivasyon unsurlarına ilişkin algı arasında anlamlı bir farklılık yoktur. $\mathrm{H}_{2 \mathrm{e}}$ hipotezi bu nedenle kabul edilmiştir (Tablo 9).

\section{Demografik Özellikler ile Verimliliğe Yönelik Algı Arasındaki Farklılıklara İlişkin Anova Analizi Sonuçlar}

Tablo 10. Verimliliğe ilişkin algının cinsiyet değişkenine göre incelenmesi

\begin{tabular}{|l|c|c|c|c|c|c|c|}
\hline & & $\mathrm{n}$ & Mean & S.D. & $\mathrm{F}$ & $\mathrm{p}$ & Sonuç \\
\hline $\begin{array}{l}\text { H3a:Katılımcıların cinsiyetlerine } \\
\text { göre verimliliğe ilişkin algılarında } \\
\text { farklılık yoktur. }\end{array}$ & Erkek & 76 & 3,8914 & 0,56175 & 2,809 & 0,097 & Kabul \\
\cline { 3 - 6 } & Kadın & 30 & 4,0875 & 0,48927 & & \\
\hline
\end{tabular}

Yapılan analiz sonucunda, $\mathrm{p}>0,05$ olduğu için cinsiyet değişkeni ile verimliliğe ilişkin alg1 arasında anlamlı bir farklılık yoktur. $\mathrm{H}_{3 \mathrm{a}}$ hipotezi bu nedenle kabul edilmiştir (Tablo 10). 
Tablo 11. Verimliliğe ilişkin algının yaş değişkenine göre incelenmesi

\begin{tabular}{|c|c|c|c|c|c|c|c|}
\hline & & $\mathrm{n}$ & Mean & S.D. & $\mathrm{F}$ & $\mathrm{p}$ & Sonuç \\
\hline \multirow{5}{*}{$\begin{array}{l}\text { H3b:Katılımcıların yaşa göre } \\
\text { verimliliğe ilişkin algılarında } \\
\text { farklılık yoktur. }\end{array}$} & $\begin{array}{c}18-25 \\
\text { yas }\end{array}$ & 12 & 3,8333 & 0,45017 & \multirow{5}{*}{2,108} & \multirow{5}{*}{0,104} & \multirow{5}{*}{ Kabul } \\
\hline & $25-33$ & 20 & 3,7813 & 0,48814 & & & \\
\hline & $33-41$ & 61 & 3.9611 & 058074 & & & \\
\hline & yaş & & & & & & \\
\hline & $\begin{array}{l}41 \mathrm{ve} \\
\text { üzeri }\end{array}$ & 13 & 4,2404 & 0,46621 & & & \\
\hline
\end{tabular}

Yapılan analiz sonucunda, $p>0,05$ olduğu için yaş değişkeni ile verimliliğe ilişkin algı arasında anlamlı bir farklılık yoktur. $\mathrm{H}_{3 \mathrm{~b}}$ hipotezi bu nedenle kabul edilmiştir (Tablo 11).

Tablo 12. Verimliliğe ilişkin algının eğitim durumu değişkenine göre incelenmesi

\begin{tabular}{|c|c|c|c|c|c|c|c|}
\hline & & $\mathrm{n}$ & Mean & S.D. & $\bar{F}$ & $\mathrm{p}$ & Sonuç \\
\hline \multirow{4}{*}{ 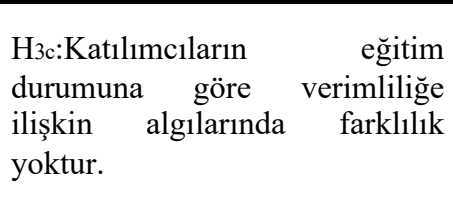 } & Lise & 14 & 4,0714 & 0,34916 & \multirow{4}{*}{1,124} & \multirow{4}{*}{0,349} & \multirow{4}{*}{ Kabul } \\
\hline & Önlisans & 22 & 4,0398 & 0,40713 & & & \\
\hline & Lisans & 66 & 3,8712 & 0,61939 & & & \\
\hline & $\begin{array}{l}\text { Master / } \\
\text { Doktora }\end{array}$ & 4 & 4,3750 & 0,21651 & & & \\
\hline
\end{tabular}

Yapılan analiz sonucunda, $\mathrm{p}>0,05$ olduğu eğitim durumu değişkeni ile verimliliğe ilişkin alg1 arasında anlamlı bir farklılık yoktur. $\mathrm{H} 3{ }_{\mathrm{c}}$ hipotezi bu nedenle kabul edilmiştir (Tablo 12).

Tablo 13. Verimliliğe ilişkin algının unvan değişkenine göre incelenmesi

\begin{tabular}{|c|c|c|c|c|c|c|c|}
\hline & & $\mathrm{n}$ & Mean & S.D. & $\mathrm{F}$ & $\mathrm{p}$ & Sonuç \\
\hline \multirow{6}{*}{$\begin{array}{l}\text { H3d:Katılımcıların unvana } \\
\text { göre verimliliğe ilişkin } \\
\text { algılarında farklılık yoktur. }\end{array}$} & $\begin{array}{c}\text { İdari İşler Yazı } \\
\text { İşleri Müdür }\end{array}$ & 16 & 4,0547 & 0,65981 & \multirow{6}{*}{1,031} & \multirow{6}{*}{0,403} & \multirow{6}{*}{ Kabul } \\
\hline & Z. Katibi & 58 & 3,8642 & 0,57938 & & & \\
\hline & Mübaşir & 16 & 3,9844 & 0,42543 & & & \\
\hline & Teknisyen & 3 & 4,2500 & 0,25000 & & & \\
\hline & Şoför & 4 & 3,7813 & 0,31250 & & & \\
\hline & Hizmetli & 9 & 4,1944 & 0,37034 & & & \\
\hline
\end{tabular}

Yapılan analiz sonucunda, $\mathrm{p}>0,05$ olduğu için unvan değişkeni ile verimliliğe ilişkin alg1 arasında anlamlı bir farklılık yoktur. $\mathrm{H}_{3 \mathrm{~d}}$ hipotezi bu nedenle kabul edilmiştir (Tablo 13). 
Tablo 14. Verimliliğe ilişkin algının çalışma süreleri değişkenine göre incelenmesi

\begin{tabular}{|c|c|c|c|c|c|c|c|}
\hline & & $\mathrm{n}$ & Mean & S.D. & $\mathrm{F}$ & $\mathrm{p}$ & Sonuç \\
\hline \multirow{6}{*}{$\begin{array}{l}\text { H3e:Katılımcıların çalışma süresi- } \\
\text { ne göre verimliliğe ilişkin } \\
\text { algılarında farklılık yoktur. }\end{array}$} & $\begin{array}{c}2 \\
\text { y1ldan } \\
\text { az }\end{array}$ & 9 & 3,9306 & 0,37558 & \multirow{6}{*}{0,995} & \multirow{6}{*}{0,40} & \multirow{6}{*}{ Kabul } \\
\hline & $\begin{array}{l}2-5 \\
Y_{11}\end{array}$ & 9 & 3,7083 & 0,37500 & & & \\
\hline & $\begin{array}{c}5-10 \\
Y_{1} 1\end{array}$ & 40 & 3,9500 & 0,53018 & & & \\
\hline & $10-15$ & 34 & 3,9191 & 0,65632 & & & \\
\hline & $15-25$ & 12 & 4,1146 & 0,46606 & & & \\
\hline & $\begin{array}{c}25 \mathrm{y} 1 \mathrm{l} \\
\text { üstü }\end{array}$ & 2 & 4,5000 & 0,35355 & & & \\
\hline
\end{tabular}

Yapılan analiz sonucunda, $\mathrm{p}>0,05$ olduğu için çalışma süresi değişkeni ile verimliliğe ilişkin algı arasında anlamlı bir farklılık yoktur. $\mathrm{H}_{3 \mathrm{e}}$ hipotezi bu nedenle kabul edilmiştir (Tablo 14).

\section{Demografik Özellikler ile İçsel Motivasyona Yönelik Algı Arasındaki Farklılıklara illişkin Anova Analizi Sonuçları}

Tablo 15. İçsel motivasyona ilişkin algının cinsiyet değişkenine göre incelenmesi

\begin{tabular}{|l|c|c|c|c|c|c|c|}
\hline & & $\mathrm{n}$ & Mean & S.D. & $\mathrm{F}$ & $\mathrm{p}$ & Sonuç \\
\hline $\begin{array}{l}\text { H4a:Katılımcıların cinsiyetlerine } \\
\text { göre motivasyon unsurlarına }\end{array}$ & Erkek & 76 & 4,2259 & 0,48664 & 0,001 & 0,975 & Kabul \\
\cline { 2 - 6 } $\begin{array}{l}\text { ilişkin algılarında farklılık yoktur. } \\
\text { ilin }\end{array}$ & 30 & 4,2222 & 0,63326 & & & \\
\hline
\end{tabular}

Yapılan analiz sonucunda, $\mathrm{p}>0,05$ olduğu için cinsiyet değişkeni ile içsel motivasyon unsurlarına ilişkin algı arasında anlamlı bir farklılık yoktur. $\mathrm{H}_{4 \mathrm{a}}$ hipotezi bu nedenle kabul edilmiştir (Tablo 15).

Tablo 16. İçsel motivasyona ilişkin algının yaş değişkenine göre incelenmesi

\begin{tabular}{|c|c|c|c|c|c|c|c|}
\hline & & $\mathrm{n}$ & Mean & S.D. & $\bar{F}$ & $\mathrm{p}$ & Sonuç \\
\hline \multirow{5}{*}{$\begin{array}{l}\text { H4b:Katılımcıların yaşa göre içsel } \\
\text { motivasyon unsurlarına ilişkin } \\
\text { algılarında farklılı yoktur. }\end{array}$} & $\begin{array}{c}18-25 \\
\text { yaş }\end{array}$ & 12 & 4,3472 & 0,32144 & \multirow{5}{*}{0,900} & \multirow{5}{*}{0,444} & \multirow{5}{*}{ Kabul } \\
\hline & $25-33$ & 20 & 4,0750 & 0,60086 & & & \\
\hline & yaş & 61 & 4202 & $0-52$ & & & \\
\hline & $\begin{array}{c}J 3-41 \\
\text { yaş }\end{array}$ & 01 & $4,20<J$ & 0,52393 & & & \\
\hline & $\begin{array}{l}41 \text { ve } \\
\text { üzeri }\end{array}$ & 13 & 4,1667 & 0,58926 & & & \\
\hline
\end{tabular}

Yapılan analiz sonucunda, $\mathrm{p}>0,05$ olduğu için yaş değişkeni ile içsel motivasyon unsurlarına ilişkin algı arasında anlamlı bir farklılık yoktur. $\mathrm{H}_{4 \mathrm{~b}}$ hipotezi bu nedenle kabul edilmiştir (Tablo 16). 
Tablo 17. İçsel motivasyona ilişkin algının eğitim durumu değişkenine göre incelenmesi

\begin{tabular}{|c|c|c|c|c|c|c|c|}
\hline & & $\mathrm{n}$ & Mean & S.D. & $\bar{F}$ & $\mathrm{p}$ & Sonuç \\
\hline \multirow{4}{*}{$\begin{array}{l}\text { H4c:Katılımcıların eğitim } \\
\text { durumuna göre içsel motivasyon } \\
\text { unsurlarına ilişkin algılarında } \\
\text { farklılık yoktur. }\end{array}$} & Lise & 14 & 4,3452 & 0,38930 & \multirow{4}{*}{0,241} & \multirow{4}{*}{0,914} & \multirow{4}{*}{ Kabul } \\
\hline & Önlisans & 22 & 4,2348 & 0,54593 & & & \\
\hline & Lisans & 66 & 4,1944 & 0,56355 & & & \\
\hline & $\begin{array}{l}\text { Master / } \\
\text { Doktora }\end{array}$ & 4 & 4,2222 & 0,34694 & & & \\
\hline
\end{tabular}

Yapılan analiz sonucunda, $\mathrm{p}>0,05$ olduğu eğitim durumu değişkeni ile içsel motivasyon unsurlarına ilişkin algı arasında anlamlı bir farklılık yoktur. $\mathrm{H}_{4 c}$ hipotezi bu nedenle kabul edilmiştir (Tablo 17).

Tablo 18. İçsel motivasyona ilişkin algının unvan değişkenine göre incelenmesi

\begin{tabular}{|c|c|c|c|c|c|c|c|}
\hline & & $\mathrm{n}$ & Mean & S.D. & $\bar{F}$ & $\mathrm{p}$ & Sonuç \\
\hline \multirow{6}{*}{$\begin{array}{l}\text { H4d:Katılımcıların unvana } \\
\text { göre içsel motivasyon } \\
\text { unsurlarına ilişkin } \\
\text { algılarında farklılık yoktur. }\end{array}$} & $\begin{array}{c}\text { İdari İşler Yazı } \\
\text { İşleri Müdür }\end{array}$ & 16 & 4,2500 & 0,74287 & \multirow{6}{*}{0,361} & \multirow{6}{*}{0,874} & \multirow{6}{*}{ Kabul } \\
\hline & Z. Katibi & 58 & 4,2069 & 0,53921 & & & \\
\hline & Mübaşir & 16 & 4,3542 & 0,35940 & & & \\
\hline & Teknisyen & 3 & 4,2778 & 0,19245 & & & \\
\hline & Şoför & 4 & 4,0417 & 0,15957 & & & \\
\hline & Hizmetli & 9 & 4,1296 & 0,52907 & & & \\
\hline
\end{tabular}

Yapılan analiz sonucunda, $\mathrm{p}>0,05$ olduğu için unvan değişkeni ile içsel motivasyon unsurlarına ilişkin algı arasında anlamlı bir farklılık yoktur. $\mathrm{H}_{4 \mathrm{~d}}$ hipotezi bu nedenle kabul edilmiştir (Tablo $18)$.

Tablo 19. İçsel motivasyona ilişkin algının çalışma süreleri değişkenine göre incelenmesi

\begin{tabular}{|c|c|c|c|c|c|c|c|}
\hline & & $\mathrm{n}$ & Mean & S.D. & $\mathrm{F}$ & $\mathrm{p}$ & Sonuç \\
\hline \multirow{6}{*}{$\begin{array}{l}\text { H4e:Katılımcıların çalışma sürele- } \\
\text { rine göre içsel motivasyon } \\
\text { unsurlarına ilişkin algılarında } \\
\text { farklılık yoktur. }\end{array}$} & $\begin{array}{c}2 \\
\text { y1ldan } \\
\text { az }\end{array}$ & 9 & 4,4259 & 0,32394 & \multirow{6}{*}{1,384} & \multirow{6}{*}{0,374} & \multirow{6}{*}{ Kabul } \\
\hline & $\begin{array}{l}2-5 \\
Y_{11}\end{array}$ & 9 & 4,1111 & 0,30046 & & & \\
\hline & $5-10$ & 40 & 4,2208 & 0,45195 & & & \\
\hline & $10-15$ & 34 & 4,2255 & 0,67779 & & & \\
\hline & $15-25$ & 12 & 4,0694 & 0,53870 & & & \\
\hline & $\begin{array}{c}25 \mathrm{y} 11 \\
\text { üstü }\end{array}$ & 2 & 4,8333 & 0,00000 & & & \\
\hline
\end{tabular}

Yapılan analiz sonucunda, $\mathrm{p}>0,05$ olduğu için çalışma süresi değişkeni ile içsel motivasyon unsurlarına ilişkin algı arasında anlamlı bir farklılık yoktur. $\mathrm{H}_{4 \mathrm{e}}$ hipotezi bu nedenle kabul edilmiştir (Tablo 19). 


\section{Demografik Özellikler ile Dışsal Motivasyona Yönelik Algı Arasındaki Farklılıklara illişkin Anova Analizi Sonuçları}

Tablo 20. Dışsal motivasyona ilişkin algının cinsiyet değişkenine göre incelenmesi

\begin{tabular}{|l|c|c|c|c|c|c|c|}
\hline & & $\mathrm{n}$ & Mean & S.D. & $\mathrm{F}$ & $\mathrm{p}$ & Sonuç \\
\hline $\begin{array}{l}\text { H5a:Katılımcıların cinsiyetlerine } \\
\text { göre dişsal motivasyon unsurlarına }\end{array}$ & Erkek & 76 & 4,3596 & 0,50994 & 1,459 & 0,230 & Kabul \\
\cline { 2 - 6 } \begin{tabular}{l} 
ilişkin algılarında farklılık yoktur. \\
\cline { 2 - 6 }
\end{tabular} & Kadın & 30 & 4,4889 & 0,45981 & & & \\
\hline
\end{tabular}

Yapılan analiz sonucunda, $\mathrm{p}>$ 0,05 olduğu için cinsiyet değişkeni ile dişsal motivasyon unsurlarına ilişkin algı arasında anlamlı bir farklılık yoktur. $\mathrm{H}_{5 \mathrm{a}}$ hipotezi bu nedenle kabul edilmiştir (Tablo 20).

Tablo 21. Dışsal motivasyona ilişkin algının yaş değişkenine göre incelenmesi

\begin{tabular}{|c|c|c|c|c|c|c|c|}
\hline & & $\mathrm{n}$ & Mean & S.D. & $\mathrm{F}$ & $\mathrm{p}$ & Sonuç \\
\hline \multirow{4}{*}{$\begin{array}{l}\text { H5b:Katılımcıların yaşa göre dişsal } \\
\text { motivasyon unsurlarına ilişkin } \\
\text { algılarında farklılık yoktur. }\end{array}$} & $\begin{array}{c}18-25 \\
\text { yaş }\end{array}$ & 12 & 4,4167 & 0,44096 & \multirow{4}{*}{0,887} & \multirow{4}{*}{0,450} & \multirow{4}{*}{ Kabul } \\
\hline & $25-33$ & 20 & 4,2333 & 0,46954 & & & \\
\hline & $\begin{array}{c}33-41 \\
\text { yaş }\end{array}$ & 61 & 4,4344 & 0,51305 & & & \\
\hline & $\begin{array}{l}41 \mathrm{ve} \\
\text { üzeri }\end{array}$ & 13 & 4,4487 & 0,51543 & & & \\
\hline
\end{tabular}

Yapılan analiz sonucunda, $\mathrm{p}>0,05$ olduğu için yaş değişkeni ile dışsal motivasyon unsurlarına ilişkin algı arasında anlamlı bir farklılık yoktur. $\mathrm{H}_{5 \mathrm{~b}}$ hipotezi bu nedenle kabul edilmiştir (Tablo 21).

Tablo 22. Dışsal motivasyona ilişkin algının eğitim durumu değişkenine göre incelenmesi

\begin{tabular}{|c|c|c|c|c|c|c|c|}
\hline & & $\mathrm{n}$ & Mean & S.D. & $\bar{F}$ & $\bar{p}$ & Sonuç \\
\hline \multirow{4}{*}{$\begin{array}{lr}\text { H5c:Katılımcıların } & \text { eğitim } \\
\text { durumuna göre } & \text { motivasyon } \\
\text { unsurlarına ilişkin } & \text { algılarında } \\
\text { farklılık yoktur. }\end{array}$} & Lise & 14 & 4,3333 & 0,46225 & \multirow{4}{*}{0,089} & \multirow{4}{*}{0,986} & \multirow{4}{*}{ Kabul } \\
\hline & Önlisans & 22 & 4,4167 & 0,48998 & & & \\
\hline & Lisans & 66 & 4,4040 & 0,52139 & & & \\
\hline & $\begin{array}{l}\text { Master / } \\
\text { Doktora }\end{array}$ & 4 & 4,3333 & 0,44096 & & & \\
\hline
\end{tabular}

Yapılan analiz sonucunda, $\mathrm{p}>0,05$ olduğu eğitim durumu değişkeni ile dışsal motivasyon unsurlarına ilişkin algı arasında anlamlı bir farklılık yoktur. $\mathrm{H}_{5 c}$ hipotezi bu nedenle kabul edilmiştir (Tablo 22). 
Tablo 23. Dışsal motivasyona ilişkin algının unvan değişkenine göre incelenmesi

\begin{tabular}{|c|c|c|c|c|c|c|c|}
\hline & & $\mathrm{n}$ & Mean & S.D. & $\overline{\mathrm{F}}$ & $\mathrm{p}$ & Sonuç \\
\hline \multirow{6}{*}{$\begin{array}{l}\text { H5d:Katılımcıların unvana } \\
\text { göre motivasyon unsurla- } \\
\text { rına ilişkin algılarında } \\
\text { farklılık yoktur. }\end{array}$} & $\begin{array}{c}\text { İdari İşler Yazı } \\
\text { İşleri Müdür }\end{array}$ & 16 & 4,3958 & 0,75492 & \multirow{6}{*}{1,005} & \multirow{6}{*}{0,419} & \multirow{6}{*}{ Kabul } \\
\hline & Z. Katibi & 58 & 4,3707 & 0,41068 & & & \\
\hline & Mübaşir & 16 & 4,5104 & 0,50358 & & & \\
\hline & Teknisyen & 3 & 4,8889 & 0,19245 & & & \\
\hline & Şoför & 4 & 4,2083 & 0,25000 & & & \\
\hline & Hizmetli & 9 & 4,2778 & 0,55902 & & & \\
\hline
\end{tabular}

Yapılan analiz sonucunda, $\mathrm{p}>0,05$ olduğu için unvan değişkeni ile dişsal motivasyon unsurlarına ilişkin algı arasında anlamlı bir farklılık yoktur. $\mathrm{H}_{5 \mathrm{~d}}$ hipotezi bu nedenle kabul edilmiştir (Tablo 23).

Tablo 24. Dışsal motivasyona ilişkin algının çalışma süreleri değişkenine göre incelenmesi

\begin{tabular}{|c|c|c|c|c|c|c|c|}
\hline & & $\mathrm{n}$ & Mean & S.D. & $\bar{F}$ & $\mathrm{p}$ & Sonuç \\
\hline \multirow{6}{*}{$\begin{array}{l}\text { H5e:Katılımcıların çalışma sürele- } \\
\text { rine göre dışsal motivasyon } \\
\text { unsurlarına ilişkin algılarında } \\
\text { farklılık yoktur. }\end{array}$} & $\begin{array}{c}2 \\
\text { y1ldan } \\
\text { az }\end{array}$ & 9 & 4,4630 & 0,44704 & \multirow{6}{*}{0,456} & \multirow{6}{*}{0,808} & \multirow{6}{*}{ Kabul } \\
\hline & $\begin{array}{c}2-5 \\
\text { Y11 }\end{array}$ & 9 & 4,2407 & 0,39185 & & & \\
\hline & $\begin{array}{c}5-10 \\
Y_{11}\end{array}$ & $\overline{40}$ & 4,3667 & 0,40510 & & & \\
\hline & $10-15$ & 34 & 4,4216 & 0,63064 & & & \\
\hline & $15-25$ & 12 & 4,4306 & 0,52444 & & & \\
\hline & $\begin{array}{c}25 \mathrm{y} 11 \\
\text { üstü }\end{array}$ & 2 & 4,7500 & 0,11785 & & & \\
\hline
\end{tabular}

Yapılan analiz sonucunda, $\mathrm{p}>$ 0,05 olduğu için çalışma süresi değişkeni ile motivasyon unsurlarına ilişkin algı arasında anlamlı bir farklılık yoktur. $\mathrm{H}_{5 e}$ hipotezi bu nedenle kabul edilmiştir (Tablo 24).

\section{Sonuç ve Öneriler}

İnsanoğlunun birlikte yaşama geçmesiyle belirginleşen, eski zamanların ilkel kabile anlayışından devletleşmeye yönelme sürecinin getirmiş olduğu en önemli değişikliklerden biri adalet hizmetlerinin devlet tekeline alınmasıdır. Günümüzde bireysel hak ve özgürlüklerin teminatı olan adaletin tesisi mahkemeler ve savcılıklar aracılığıla yerine getirilmektedir. Yargı mercileri vermiş oldukları kararlarla bireylerin hukuki kaderini şekillendirmektedir. $\mathrm{Bu}$ bağlamda önemli bir görev ifa eden yargı çalışanlarının motive olmaları ve verimli çalışmaları; sürece olan katkıları ve mevcut iş yükleri nedeniyle önem arz etmektedir. Kısa bir istatistik belirtmek gerekir ise, Adalet Bakanlığı Adli Sicil ve İstatistik Genel Müdürlüğü’nce yayınlanan verilere göre 2016 yılı itibariyle, 7.393 .618 adet soruşturma yürütülen dosya, 2.406 .5372 ceza dava dosyası, 3.524.898 hukuk dava dosyası bulunmaktadır. Yine aynı istatistik çalışmasına göre birçok unvan grubu bulunmakla birlikte Adalet Bakanlığı, 2016 yılında 4.990 yazı işleri müdürü, 228 idari işler müdürü, 30.918 zabıt kâtibi, 4.788 mübaşir olmak üzere 56.579 çalışanı 
bünyesinde barındırmaktadır. Yargı çalışanlarının sayısı ile mevcut iş yükü karşılaştırıldığında hâkim ve savcılar dışındaki yargı çalışanlarının motivasyon ve verimliliğinin önemi daha da belirginleşmektedir. Öyle ki yakın zamanda Adalet Bakanlığı tarafından iş yükünün hafifletilmesi amacıyla bazı suçlar soruşturma aşamasında uzlaştırmacı kişiler tarafından davanın tarafları arasında uzlaşı sağlanmak suretiyle çözümlenmekte, bir kısım davalar ise arabulucular marifetiyle çözüme kavuşturularak dava açlmasının önüne geçilmeye çalışılmaktadır. Bu suretle yargının iş yükünü hafifletmeye yönelik alternatif uygulamalar söz konusudur.

Öte yandan adaletin doğru tecellisi yanında en kısa sürede tecelli ettirilmesi de ayrı bir önem arz etmektedir. Zira çoğu zaman ülke genelinde geç gelen adaletten şikâyet edildiği bilinmektedir. Bu açıdan da çalışanlar, adaletin doğru ve en kısa zamanında tecellisi açısından önemli görevler üstlenmektedirler. Çalışmanın ana ekseni yargı çalışanlarının üstlendikleri fonksiyonun hayati önemi ve iş yükü dikkate alınarak onların motive olmalarını sağlayan unsurlardan bir kısmının irdelenmesi, motive olmaları ve verimli çalışmalarını sağlamak amacıyla bir takım önerilerin sunulmasıdır.

Türk kamu yönetiminde personel motivasyonu ve verimlik üzerine etkisini incelemeye yönelik Erzurum Bölge Adliye Mahkemesi çalışanlarına ilişkin yapılan bu araştırmada aşağıdaki sonuçlar elde edilmiştir.

Katılımcılar çoğunlukla 33-41 yaş aralığında, lisans düzeyinde eğitim almış, 5-10 yıl arası bir çalışma süresine sahip, zabıt kâtibi kadrosunda görev yapan erkek ve kadınlardan oluşmaktadır. Motivasyon açısından başarılı olmanın erkek çalışanları daha çok motive ettiği, erkek çalışanların kadın çalışanlara nazaran iş ile ilgili sorumluluk almaktan kaçındıkları, işin yapılmaya değer bir iş olduğuna erkek çalışanların daha fazla inandıkları, yöneticilerin onurlandıran tavır ve davranışlarını kadın çalışanların daha çok önemsedikleri, yapılan işle ilgili olarak bireysel insiyatif alabilmenin erkek çalışanları daha çok motive ettiği, başarıdan dolayı ödüllendirmenin hem erkek hem kadın çalışanlar açısından önemli görüldüğü, fiziksel çalışma koşullarının kadın çalışanlar açısından daha önemli bulunduğu, işte terfi olanaklarının bulunması, iş yerindeki araç ve gereç yeterliliğinin yanı sıra kişisel gelişime yönelik toplantı, seminer, eğitim gibi faaliyetlerin ve yemek, çay gibi imkânların bulunmasının kadın çalışanlar açısından daha motive edici olduğu, alınan ücret miktarının ise erkek çalışanları daha çok motive ettiği tespit edilmiştir. Verimlilik açısından kadın çalışanların işini daha çok severek yaptıkları, iş yapılırken erkeklerin israfı önlemeye karşı daha duyarlı oldukları, mesleki gelişim için kongre, kurs ve seminer gibi etkinlikleri kadınların daha çok önemsedikleri, her iki çalışan grubunun da iş yoğunluğunun hata yapmalarını kolaylaştıracağı görüşünde buluştukları, terfi ve ilerleme olanaklarının sınırlı olmasının çalışma isteklerini azaltacağı, iş güvencesinin önemli olduğu, birimdeki yöneticilerin huzurlu bir çalışma ortamı sağlamaya gayret ettiklerini düşündükleri, kurumdaki fiziki ve teknik alt yapı eksikliklerin işlerini aksatacağını düşündükleri görülmüştür. Anket sorularına verilen cevaplara göre kadın çalışanların erkek çalışanlara nazaran daha çok motivatörlerin etkisinde kaldıkları ve benzer şekilde bu faktörlerin verimlilik üzerine etkili olduğu görüşünde buluştukları görülmektedir. Erzurum Bölge Adliye 
Mahkemesi personelinin anket sorularına ilişkin düşünceleri yorumlandığında, mevcut literatür çalışmalarında elde edilen bulgulara paralel olarak yeterince güçlü olmasa da motivasyon faktörlerinin verimliliği artırıcı bir unsur olduğu sonucuna ulaşılmıştır. Ancak verimliliği artırmak için tek başına bu motivasyon araçlarının yeterli olduğunu kabul etmek mümkün değildir. Zira motivasyon faktörlerinin bireysel olarak değişkenlik gösterdiği daha önce bu alanda yapılan çalışmalardan ulaşılmış ve genel kabul gören sonuçlardan biridir. $\mathrm{Bu}$ nedenle elde edilen sonuçlardan çıkarılabilecek ilk öneri alanında uzman, insan odaklı bir personel yönetiminde, bireysel farklılıkları dikkate alan çalışmalar sonucu verimliliği artıracak motivasyon faktörlerinin belirlenmesi ve bu doğrultuda uygulamaların hayata geçirilmesi hedeflenmelidir.

Verimliliği artıracağı düşünülen motivasyon faktörlerinin yasal mevzuat sınırlamaları nedeniyle personel bazında uygulanma olanağı sınırlıdır. Çünkü kurum çalışanları arasında performansa dayalı bir ödüllendirme söz konusu değildir. Bu nedenle çalışan - çalışmayan ayrımını belirginleştirecek, bireysel başarıları daha çok destekleyecek, verimliliğe olan katkıların çalışan bazında daha olumlu sonuçlar doğurmasını sağlayacak biçimde bireysel ödüllendirmelere imkân sunacak, insan kaynakları odaklı, yeni, esnek, belirgin ve uygulanabilir, küresel ve başarılı örneklerle uyumlu yasal mevzuat düzenlemeleri hayata geçirilmeli, çalışanların motivasyonunu artıran unsurlar ekseninde belirgin bir yapılaşma, çalışma düzenin kurgulanması ikinci öneridir.

Kurum nezdinde yargı sürecinin hızlandırılmasına yönelik bir çok yargısal reform çalışmaları mevcuttur ancak personel faktörünün bu sürece dahil edilmediği görülmektedir. Örneğin yargılama süreçlerinin belirli bir süre sınırı konulmak suretiyle oluşturulan hedef süre uygulamasında çalışanların katkıları ve bu hedefe ulaşmadaki rolleri göz ardı edilmiştir. Bu faydalı hedefin olumlu sonuç doğurması açısından çalışan katkısının da dikkate alınması gerekmektedir. Bu amaçla, üçüncü öneri olarak yapılacak reformlarda çalışanlara düşen ödevler açıkça belirlenmeli, hedeflere ulaşmadaki katkıları sorgulanmalı, stratejiler ortaya konulmalı ve çalışanların motivasyon ve verimliliğinin bu sürece sunacağı olumlu katkı desteklenmelidir.

Anket sonuçlarına göre çalışanlar daha çok dışsal motivasyon araçlarının motivasyonu artırdığ görüşündedirler. $\mathrm{Bu}$ tespitten hareketle motivasyon uygulamalarında dışsal motivasyon araçlarından yararlanılmasına daha çok özen gösterilmesi, bu araçların neler olduğu yönünde çalışanlar arasında gerek anket gerek bilgi toplama yöntemi ile sağlıklı verilere ulaşılması gerektiği düşünülmektedir.

Son olarak sosyal bilimler alanında yapılan bu çalışma bölge adliye mahkemelerinde ilk çalışma niteliğinde olup, yargı çalışanlarının motivasyonlarına ilişkin çalışmalara ve verimliliğinin artırılmasına yönelik yapılacak düzenlemelere katkı sunacağı ve literatürün zenginleştirilmesine yardımcı olacağı düşünülmektedir. 


\section{Kaynakça}

Abacı, K. (2015, Ekim). Kamu sektöründe çalışanların motivasyonlarının, verimlilik üzerindeki etkilerine yönelik bir saha çalışması. 5. Ulusal Verimlilik Kongresinde sunulan bildiri, Ankara. Erişim adresi: https://anahtar.sanayi.gov.tr/tr/flipbook/kasim-2015/1066

Akdemir, A. (2003). Temel İsletmecilik Bilgileri. İstanbul: Türkmen Kitabevi.

Ateş, H., Yıldız, B. \& Yıldız, H. (2012). Herzberg'in çift faktör kuramı kamu okullarında çalışan öğretmenlerin motivasyon algılarını açıklayabilir mi? ampirik bir araştırma. Bilgi Ekonomisi ve Yönetimi Dergisi, 7(2), 147-162.

Aydın, A. (1999). İmalat sanayi ve alt kollarında verimlilik, üretim, istihdam, ücret ve işçi, saat göstergeleri. Ankara: MPM.

Barlı, Ö. (2015). Davranış bilimleri ve örgütlerde davranış. İstanbul: Akif Yayın Evi.

Binbaşıŏlu, E. (1992). Endüstri psikolojisi. Ankara: Kadıŏlu Matbaası.

Brislin, R. W., Kabigting, F., Macnab, B., Zukıs, B., Worthley, R. (2005). Evolving perceptions of Japanese workplace motivation. International Journal of Cross Cultural Management, 5, 87-113. doi: 10.1177/1470595805050829

Deligöz, K. \& Güzel D. (2016). Verimlilik açısından zaman yönetimi ve Erzurum adliyesi uygulamas1. Türkiye Adalet Akademisi Dergisi, 27, 437-449.

Deniz, M. (2005). Örgütsel davranış boyutlarından seçmeler. Ankara: Nobel.

Doğan, A. \& Aydın, A. (1991). İmalatçı kamu kuruluşlarında maliyet ve verimlilik karşılaştırmaları. Ankara: MPM.

Doğan, S. (2003). Çalışanların verimliliğinin arttırılmasında ergonomi ve önemi. Standard Ekonomik ve Teknik Dergisi, 496, 33-39.

Durmuş, B., Yurtkoru, E. S. \& Çinko, M. (2016). Sosyal bilimlerde SPSS'le veri analizi (6. Baskı). İstanbul: Beta Basım Yayım.

Dündar, S., Özutku, H. \& Taşpınar, F. (2007). İçsel ve dışsal motivasyon araçlarının işgörenlerin motivasyonu üzerindeki etkisi: Ampirik bir inceleme. Gazi Üniversitesi Ticaret ve Turizm Eğitim Fakültesi Dergisi, 2(1), 105-119.

Ekinci, F. (2008). Kamu personel yönetiminden insan kaynakları uygulamasına geçişin çalışanların verimliliğine etkisi. Maliye Dergisi, 155, 175-185.

Eren, E. (2004). Örgütsel davranıs ve yönetim psikolojisi. İstanbul: Beta.

Eren, E. (2013). Yönetim ve organizasyon. İstanbul: Beta Basım Yayım Dağıtım.

Erkut, H. (1992). Verimlilik ve özendirme. Verimlilik Dergisi, 21(4), 15-16.

Eroğlu, F. (2015). Davranış bilimleri. İstanbul: Beta Basım Yayım Dağıtım.

Fındıkçı, İ. (2000). İnsan kaynakları yönetimi. İstanbul: Alfa.

Güngör, P. (2011). The relationship between reward management system and employee performance with the mediating role of motivation: A quantitative study on global banks. Procedia-Social and Behavioral Sciences, 24, 1510-1520.

Göktepe, N. (2010). Hemşirelerin verimliliğe ilişkin tutumları ve bir ölçek geliştirme çalışması. (Yayımlanmamış Doktora Tezi). İstanbul Üniversitesi, Sağlık Bilimleri Enstitüsü, İstanbul.

İslamoğlu, A. H. (2011). Sosyal bilimlerde araştırma yöntemleri. İstanbul: Beta Basım Yayım Dağıtım.

Karakaş, Z., (2010). Yönetime katılmanın iş tatmini üzerine etkisi: Denizli'de tekstil sektöründe bir uygulama (Yayımlanmamış Yüksek Lisans Tezi). Dumlupınar Üniversitesi, Sosyal Bilimler Enstitüsü, Kütahya. 
Koçel, T. (2001). İşletme yöneticiliği: Yönetim ve organizasyon, organizasyonlarda davranış, klasik - modern - çă̆daşv ve güncel yaklaşımlar. İstanbul: Beta.

Korkmaz, A. (1997). Türk imalat sanayiinden verimlilik göstergeleri. Ankara: Milli Prodüktivite.

Kuşluvan, Z. (1999). Örgütlerde motivasyonun önemi ve kullanılan motivasyon araçları.

Insan Kaynakları ve Yönetim Dergisi, 3, 55-64.

López-Ortega, E. \& Saloma-Velazquez, R. (2002). A worker productivity model. Proceedings of the 20 th International Conference of the System Dynamics Society, Palermo, Italy. doi:10.13140/RG.2.1.4477.2085

Mahaney C. R. \& Lederer A. L. (2006). The effect of intrinsic and extrinsic rewards for developers on information systems project success. Project Management Journal, 37(4), 42-54. doi: $10.1177 / 875697280603700405$

Mott, P. (1972). The characteristic of effective organization. New York, NY: Harper and Row Publisher.

Mottaz J. C. (1985). The relative importance of intrinsic and extrinsic rewards as determinants of work satisfaction, The Sociological Quarterly, 26(3), 365-385.

Öztürk, K. (2004). Kamu yönetiminde verimlilik, Türk İdare Dergisi, 445, 1-18.

Pekel, H, N. (2001). İşletmelerde motivasyon - verimlilik ilişkisi devlet hava meydanları işletmesi Antalya havalimanı çalışanları arasında bir örnek olay araştırması (Yayımlanmamış Yüksek Lisans Tezi). Süleyman Demirel Üniversitesi, Sosyal Bilimler Enstitüsü, Isparta.

Prokepenko, J. (1992), Verimlilik yönetimi uygulamalı el kitabı. Olcay Baykal, Nevda Atalay \& Erdemir Fidan (Çev.), Ankara: Milli Prodüktivite Merkezi.

Sabuncuoğlu, Z. \& Vergiliel Tüz, M. (2016). Örgütsel Davranış. Bursa: Alfa Aktüel.

Şimşek, Ş. M., Akgemci, T. \& Çelik, A. (2003). Davranış bilimlerine giriş ve örgütlerde davranış (3. baskı). Konya: Adım Matbaacılık.

Şimşek, H., \& Yıldırım, A. (2005). Sosyal bilimlerde nitel araştırma yöntemleri. Ankara: Seçkin.

Türk Dil Kurumu. Güncel Türkçe Sözlük. Erişim Adresi: http://www.tdk.gov.tr

Tekeli, M. A. (2011). Örgüt verimliliğinin artırılmasında iletişimin rolü: Bitlis Hizan Milli Ĕ̆itim Müdürlüğ̈̈ örneği (Yayımlanmamış Yüksek Lisans Tezi). Gazi Üniversitesi, Sosyal Bilimler Enstitüsü, Ankara.

Uçkun, G. \& Pelit, E. (2003). Hizmet işletmelerinde işgören motivasyonunun önemi ve verimliliğe etkisi. Standart Dergisi, 493, 49-54.

Ünlüönen, K., Ertürk, M. \& Olcay, A. (2007). Otel işletmelerinde psiko-sosyal motivasyon araçları ve bu araçların farklı departmanlar üzerindeki etkisine yönelik Ankara ve İzmir otellerinde bir uygulama. Elektronik Sosyal Bilimler Dergisi, 6(19), 9-32.

Yaşlığlu, M. M. (2017). Sosyal bilimlerde faktör analizi ve geçerlilik: Keşfedici ve doğrulayıcı faktör analizlerinin kullanılması. İstanbul Üniversitesi İşletme Fakültesi Dergisi, 46, 74-85.

Yazıcıoğlu, Y. \& Erdoğan, S. (2004). SPSS uygulamalı bilimsel araştırma yöntemleri. Ankara: Detay.

Yumuşak, S. (2008). İşgören verimliliğini etkileyen faktörlerin incelenmesine yönelik bir alan araştırması, Süleyman Demirel Üniversitesi İktisadi ve İdari Bilimler Dergisi, 7(2), 147162.

Young, P. V. (1968). Bilimsel sosyal incelemeler ve araştırma. Gazanfer Bingöl \& Necati İşçil (Çev.), Ankara: Ege Matbaası. 